\title{
Socio-Economic Benefit of Lake Ecosystem (In Case of Lake Ziway)
}

\author{
Gezahegne Seyoum Gebremedhin*, Satishkumer Belliethathan
}

Ethiopian Environment and Forest Research Institute, Addis Ababa University

* Corresponding author email: gezahegne.seyoum@yahoo.com

Received: 05 April 2019 / Revised: 30 May 2019 / Accepted: 8 July 2019 / Published: 18 July 2019

\begin{abstract}
This study focused on the socio-economic benefit of the Western shoreline of Lake Ziway ecosystem. Lake Ziway great importance for food and water for both groups of respondents and additional sources of raw material, energy, cultivation, organic fertilizers, genetic and medicinal plants. Lake Ziway also has a major economic benefit for both groups of respondents. The respondent fishermen caught a mean amount of $2,524 \mathrm{Kg}$ per year with a minimum and maximum amount of fish $504 \mathrm{Kg}$ and $16,800 \mathrm{Kg}$ per year respectively and with this fish-catching, they got an average income of $51,398 \operatorname{Birr}(\$ 2,570)$ per year with range of 7,200 $\operatorname{Birr}(\$ 360)$ and $288,000 \operatorname{Birr}(\$ 14,400)$ per year. As like of fishermen small scale irrigation also got economic benefit with their production of cereal crops, fruits, and vegetables. They produce in average 13.47Quintal of cereal crop and 69.56Quintal of fruits and vegetables per year and they got an average income of 7,727 Birr (\$386) and with a range of 13,714 Birr (\$686) per year respectively. this incurred that wetland ecosystem has a lot of socio-economic benefit for the people live nearby especially for developing countries like Ethiopia they are more dependent on a natural ecosystem like of Lake Ziway.
\end{abstract}

Keywords: Fishermen; Lake Ziway; Small scale irrigation users; Socio-economic benefit; Wetland ecosystem service

\section{Introduction}

Ecosystem goods and services defined as "outputs of ecological processes that contribute to social welfare" (Alan D. et al., 2017) and ecosystem goods and services deliver a range of multiple services that vary in quantity and quality depending on the kind of ecosystems and their natural environment (Eyasu E. et al 2019). Among these ecosystems Lake Ecosystem is one of fresh water aquatic ecosystem. The people of developing countries more depend on ecosystem goods and services of nature such as economic dependences, social well beings and livelihoods of the peoples those found around the particular ecosystem like forest ecosystem, wetland ecosystem and others (Derkzen M. et al 2017). Among these ecosystems Lake Ecosystem is one of them and it has great role to support the livelihoods of the people found around lakes (EFTEC, 2005). Economic and social development mainly expected when they are supported by ecosystems goods and services (Małgorzata C., 2017 and Janet R. et al., 2008). Ethiopian Lakes have a great benefit to social and economic wellbeing of the society however those Lakes are important to the livelihood of the nearby people; they are under threat of extinct (Yrgalem D., 2018). There are various users of ecosystem goods and services of Lake Ziway, among these users private industries like horticulture company, local farmers using small scale irrigation to agricultural activities, production fishes, using of lake Ziway water for water supply to Ziway town and gives other ecosystem goods and services.

Lake Ziway still holds the intrinsic value and aesthetic quality of a wetland, including its functions like shelter for a rich diversity of plants, aquatic birds and fish and ecological functions like filtering pollutants and sediments, buffering against wind and storm etc. (Walter V. et al., 2006). The marshes around the lake support several waders, both of intra- African and Northern species while roosts of several thousands of cormorants, ducks and geese can be observed around the lake. The long shoreline of lake Ziway is covered with submerged vegetation and especially in the south, papyrus and emergent grasses, reeds and Scymora trees, in addition the shoreline used for the irrigation purpose for farming activities and for fishery. 
Socio-Economic Benefit of Lake Ecosystem (In Case of Lake Ziway)

In the less inundated areas, the lake offers suitable farm and grazing land when the water level is low and breeding and nursery places for fish when the level is high. When properly managed and monitored, lake Ziway has a good potential for the development of tourism with a focus on wetland aesthetics with its riparian forests, hippo's and birds and making boat trips to the islands with hot water springs, local traditions and fish barbecue attractive activities (Petra et al., 2009).

Ecosystem services of lakes Ziway like fisheries, cereal crop production, vegetable and fruit production, provide food, income and employment to the rural and urban population. Instead lakes and its shoreline ecosystem are the sources of livelihood benefits; their threat of destruction around the world has often been common and is mainly caused by land reclamation and drainage (Tesfau B. et al, 2018). Lake Ziway also despite its social and economic role, the value of the ecosystem services of is undervaluing in the development planning of the area (Felegeselam ,2003). So, the purpose of the study to magnify social and economic importance of Lake Ziway for the two major groups called fishermen and small scale irrigation user in order to recall policy maker's socioeconomic importance of Lake Ziway ecosystem and in order to consider degradation of ecosystem service in developmental and environmental planning.

\section{Material and Methods}

Lake Ziway found in the Oromiya region under Eastern Showa and Arisi zones. And most of Western shoreline of Lake Ziway found in the Eastern Showa zone under Adami Tulu Jido Kombolch woreda and Dugda woreda. Lake Ziway is located at about $160 \mathrm{Km}$ South of Addis Ababa (7052'to 808'N latitude and 7052' to 38056'E longitude (Matheos Hailue,2011). The lake is situated at an altitude of $1636 \mathrm{~m}$ above sea level with a surface area of $434 \mathrm{Km}^{2}$ and mean of depth $2.5 \mathrm{~m}$. The lake is fed by rivers Meki from Noth West and Ketir from East and it has an out flow through Bulbula river, draining in to Lake Abijata. In the study mainly focused on the Western shoreline of Lake Ziway since most of economic activities were found on the Western shoreline like fisheries, small scale irrigation, livestock production, private companies such as horticulture and others.

The location of Dugda wereda is $130 \mathrm{Km}$ from Addis Ababa and $90 \mathrm{Km}$ from Adama town and neighboring weredas for are Ziway-Dugda wereda towards East, Bora wereda towards North, Adami Tulu Jidu Kombolcha (ATJK) towards South and South region of SNNPE (South Nation Nationality of Ethiopia) towards West. The total area of Dugda wereda is 95,945 ha. And the total population is 144,910 out of which 74,561 are male and 70,349 are female, in addition the number of people living in rural area are 108,658 and in urban area are 18,386. Being arid and semi-arid Dugda received $750 \mathrm{~mm}$ rainfall per year with a mean temperature of $26^{\circ} \mathrm{c}$. Location of ATJK is $7037^{\prime}-04^{\prime} \mathrm{N}, 38^{\circ} 32^{\prime}-39^{\circ} 04^{\prime} \mathrm{E}$ and $167 \mathrm{~km}$ from the capital Addis Ababa and has total area of $1403.3 \mathrm{Km}^{2}$. This wereda also has $700 \mathrm{~mm}$ annual precipitation which $42 \%$ falls in the period between June to September and the mean annual temperature is $24^{\circ} \mathrm{c}$ at Ziway and Admi Tullu station. It has arid and semi-arid ecological zone in addition the total population of this wereda is 141,405 with 71,167 are male and 70,238 are female.

In the study used both primary and secondary source of data. The primary data were collected by using survey questionnaire, interview and observation and thought for secondary source of data from literature reviews, organization documents (4 Mathewos H., 2011). The study categorized the population in to two different groups, fishermen and Small Scale Irrigation Users (SSIU) who are direct users of Lake Ziway ecosystem goods and services. And then sample from the two groups were taken semi-structured questionnaires were distributed to both groups for collecting data (Hannah M., 2019). To determine the size of sample for both groups, the study used data from ATJK woreda and Dugda woreda agricultural offices, the number of fishermen and SSIU who got ecosystem services of Western shoreline of Lake Ziway. The total number of fishermen and SSIU were 1590 and 1650 respectively in both woredas, the study used 170 sample size for each group from the total number of each groups. And from 13 kebeles which were found Western shoreline of Lake Ziway, 8 kebeles selected randomly for sampling. From the 8 kebeles 4 of them from Dugda woreda (Abiyi Gebrel, Welde Mekedela, Welde Qalina, Tuchi Dambal) and 4 of them from ATJK woreda (Ziway Batu kebele 1, Kontola, Bochessa, Abosa) selected randomly and the study 
Gebremedhin et al., Adv. J Social Sci.; Vol. 6 Issue 1, pp: 1-9, 2020

distributed the survey questionnaire for sampled household from these kebeles. For comparing economic benefit of fishermen and small-scale irrigation from Lake Ziway ecosystem, the study used independent sample t-test. And STATA version 11 and SPSS version 20 software used for analyzing data.

\section{Results and Discussion}

\subsection{Socio-Economic Characteristics of the Sample Households}

The ages of the fishermen ranged between 18 and 57 with a mean age of 31.5 with respect to age frequency most of them were of age $28,30,25,26$, with corresponding of $10.6 \%, 10.0 \%, 7.1 \%, 7.1 \%$ respectively. And out of the total 73.5 percent of the sample population were below age of 35 . The study also revealed that $98.2 \%$ were male and among the fishermen respondents $57.1 \%$ were married and $33.5 \%$ single. From the fishermen respondents $81.8 \%$ attended formal class, and 18.2\% did not any attended formal class. Most of the educated people attended class until grade 10, 6, 9 with the percentage of $16 \%, 11.2 \%$ and $10.6 \%$ respectively. The fishermen's household income varied between minimum of 6,240 birr and maximum of 234,000 birr per year. Mean income was 41,019.97 birr per year. In addition, $81.8 \%$ of the sample household earned below 56,000 birr per year and only $18.2 \%$ of the respondent earned the above state amount. 90\% of the respondent fishermen had a family size below 8 family members and the rest had above 8 family members.

From the fishermen household, the number of family members who were directly involved in the source household income activities most of their family's number are 1 and 2 in percentages of $59.4 \%$ and $28.8 \%$ respectively. Only $11.8 \%$ of the sample household had more than 2 family members participating in the household source of income activities. $37.1 \%$ of the household did not have children who went to school and $61.1 \%$ of the sample had between 1 and 5 numbers of children who attended formal class.

The age of the respondents of SSIU ranged between a minimum 22 years and a maximum of 66 years with a mean of 37.61 years. $79.4 \%$ of the respondents were below 46 years of age. $72.9 \%$ respondents were male, and the rest were female. $82.9 \%$ of the total sample households were married and $47.6 \%$ of the sample respondents did not attend formal class and $11.2 \%$ respondents were grade 10 completed. The amount of income per year of SSIU sample respondents ranged between 12,000 and 202,000 birr per year and their mean income was 58,869.2 birr per year. From the total sample household $74.7 \%$ had family size of 2 to 7 numbers, $83.5 \%$ of household had 1 upto 3 number families directly engaged in the main source of income. Among the total sample in $77.6 \%$ of the household there were 1up to 4 numbers of children attending formal class.

\subsection{Economic Benefit of Lake Ziway for Fishermen and Small Scale Irrigation Users (SSIU)}

Petra et al., (2009) and Felegeselam (2003) indicated that Lake Ziway ecosystem had economic benefit for the residents of the shoreline of Lake Ziway especially for fishermen and SSIU. The fishermen got their main house hold income by catching fishes and selling for the local fish whole sale merchants or by selling directly to the market. Small Scale Irrigation Users (SSIU) also were getting economic benefit from ecosystem services of Lake Ziway and its shoreline by producing cereal crops, vegetable and fruit which they then sold in the market. This study only dealt with on the economic benefit of Western shoreline of Lake Ziway and the following showed the amount of production, cost, income of the sample household of fishermen and SSIU (Sabine H., 2017 and Konstantine O., 2005).

From the fishermen respondents mean amount of fish produced per year is $2,524 \mathrm{Kg}$ (Table 1), with a minimum and maximum amount of fishes produced per year were 504 and 16,800 $\mathrm{Kg}$ respectively and its standard deviation is 1930. From the frequency table, it showed that the first, second, third and fourth order in percentage $15.3 \%$ of fishermen respondents were produced $2,520 \mathrm{Kg}$ of fish per year, $12.4 \%$ produced $2,100 \mathrm{Kg}$ of fishes, $11.2 \%$ produced $840 \mathrm{Kg}$ of fishes, $11.2 \%$ produced $1,680 \mathrm{Kg}$ of fishes and $10 \%$ of the fishermen respondents produced 3,360Kg of fishes per year respectively (Rob B. et al., 2017 and Russi D. et al., 2013). 
Socio-Economic Benefit of Lake Ecosystem (In Case of Lake Ziway)

The mean expense incurred for caching fish by the fishermen respondents was 12,001birr per year (Table 1) and the minimum and maximum expense were 0 and 72000 birr respectively per year and its standard deviation 9754. The frequency table showed that $90.6 \%$ of the fishermen respondents incurred expense less than 18,000 birr per year for catching fishes. In addition, the fishermen respondent's average income obtained from catching fish was 51,398.5 birr per year, their minimum and maximum income generate from catching are 7,200 and 288,000 birr per year and their standard deviation is 38,128. 94.5\% of the fishermen respondents got income from catching fish was below 90,720 birr per year (23 Ke Z., 2018).

Table 1: Amount, expense and income get by fish caching by fishermen

\begin{tabular}{|l|l|l|l|l|l|l|}
\hline & $\mathrm{N}$ & Range & Minimum & Maximum & Mean & Std. Deviation \\
\hline $\begin{array}{l}\text { Amount of fish produced } \\
\text { per year per Kg }\end{array}$ & 170 & $16,296.00$ & 504.00 & $16,800.00$ & $2,523.9529$ & $1,930.19061$ \\
\hline $\begin{array}{l}\text { Average expense of } \\
\text { fishermen } \\
\text { With fish catching per year }\end{array}$ & 170 & $72,000.00$ & .00 & $72,000.00$ & $12,001.4118$ & 9.753 .94020 \\
\hline $\begin{array}{l}\text { Amount of income of } \\
\text { fishermen } \\
\text { by fish catching in year }\end{array}$ & 170 & 280800.0 & 7200.00 & $288,000.00$ & $51,398.4706$ & $38,128.53205$ \\
\hline
\end{tabular}

The fishermen respondents indicated that they produced 1.95 and 2.37 quintal in average of cereal crops and vegetables and fruits respectively (Table 2). However, from the fishermen respondents only $16.5 \%$ of re produced cereal crop and 3.5\% of the fishermen respondents produce vegetable and fruit. Furthermore, the respondents indicated that they produced cereal crop and vegetable and fruit as part time work not as the main house hold income source because their main source of income was catching fishes from Lake Ziway (Brent M., 2009). Amount of average expense incurred by fishermen respondents for cereal crop and vegetable and fruit production were 326 and 450 birr per year (Table 2). And maximum amount of expense for cereal crop and vegetable and fruit production were 6,000 and 36,000 birr per year respectively. Average income obtained from selling cereal crop and vegetable and fruit were 248 and 1,279 birr per year accordingly.

Table 2: Amount, expense and income get by producing cereal crops and vegetable and fruit production of fishermen

\begin{tabular}{|l|l|l|l|l|l|l|}
\hline & $\mathrm{N}$ & Range & Minimum & Maximum & Mean & Std. Deviation \\
\hline $\begin{array}{l}\text { Average amount of cereal crop } \\
\text { produces per year }\end{array}$ & 170 & 40 & 0 & 40 & 1.95 & 5.571 \\
\hline $\begin{array}{l}\text { Amount of average expense used } \\
\text { for cereal crop production }\end{array}$ & 170 & 6000 & 0 & 6000 & 325.88 & 927.764 \\
\hline $\begin{array}{l}\text { Amount of average income gets by } \\
\text { selling cereal crop production }\end{array}$ & 170 & 10000 & 0 & 10000 & 248.09 & 1266.997 \\
\hline $\begin{array}{l}\text { Amount of average vegetables and } \\
\text { fruit produced per year }\end{array}$ & 170 & 200 & 0 & 200 & 2.37 & 18.152 \\
\hline $\begin{array}{l}\text { Amount of average expense used } \\
\text { for production of vegetable and } \\
\text { fruit per year in birr }\end{array}$ & 170 & 36000 & 0 & 36000 & 450.00 & 3126.358 \\
\hline $\begin{array}{l}\text { Amount of average income gets } \\
\text { from producing vegetable and fruit } \\
\text { per year in birr }\end{array}$ & 170 & 50000 & 0 & 50000 & 1279.41 & 6935.023 \\
\hline
\end{tabular}


Gebremedhin et al., Adv. J Social Sci.; Vol. 6 Issue 1, pp: 1-9, 2020

Average amount of fishes caught per year were $60.2 \mathrm{Kg}$ by SSIU, minimum and maximum amount of fish caught per year were 0 and $2,520 \mathrm{Kg}$ respectively and their standard deviation is 282 (Table 3). However, from the respondents of SSIU only 5.3\% were doing an activity of fish caching from the total respondents and they were doing fish catching in their part time.

Table 3: Amount, expense and income got by fish caching by SSIU

\begin{tabular}{|l|l|l|l|l|l|l|}
\hline & $\mathrm{N}$ & Range & Minimum & Maximum & Mean & Std. Deviation \\
\hline $\begin{array}{l}\text { Amount of fish produce } \\
\text { per year per Kg }\end{array}$ & 170 & 2520.00 & .00 & 2520.00 & 60.2824 & 282.12938 \\
\hline $\begin{array}{l}\text { Average expense by fish } \\
\text { catching per year }\end{array}$ & 170 & 10800.00 & .00 & 10800.00 & 331.7647 & 1598.83180 \\
\hline $\begin{array}{l}\text { Amount income gets by } \\
\text { fish catching in year }\end{array}$ & 170 & 54000.00 & .00 & 54000.00 & 1010.1176 & 5543.34667 \\
\hline
\end{tabular}

Average expense incurred by SSIU for fish catching was 332 birr per year (Table 3), minimum and maximum amount of expense were 0 and 10,800 birr per year and their standard deviation was 1,599. In addition, average income got with fish catching by SSIU was 1,010birr per year, minimum and maximum income obtained from fish catching by SSIU were 0 and 54,000 birr per year accordingly (Fan W. et al., 2019).

SSIU respondents produced in average 13.47 Quintal of cereal crop per year and their minimum and maximum amount of cereal crop production were 0 and 120 Quintal per year and from the sample $40 \%$ of respondents did not produce cereal crop (Table 4). The average cost incurred for cereal crop was 2,865 birr per year in addition minimum and maximum amount of cost incurred for cereal crop production were 0 and 30,000 birr per year. However, $40 \%$ of the SSIU respondents did not incurred any cost for cereal crop production. SSIU respondents also got incomes generated from cereal crop production and their average amount of income was 7,727birr per year as well as their minimum and maximum amount of income gets from selling cereal crop were 0 and 72,000 birr per year respectively (Table 4). But 56.5\% of SSIU respondents did not get income by selling cereal crop because $40 \%$ of the respondents did not produce cereal crop and $16.5 \%$ of SSIU respondents used cereal crop for home consumption not for selling in the market (Christina P. et al., 2017).

Table 4: Amount of production, cost and income by producing cereal crops and vegetable and fruit of SSIU

\begin{tabular}{|l|l|l|l|l|l|}
\hline & $\mathrm{N}$ & Minimum & Maximum & Mean & Std. Deviation \\
\hline $\begin{array}{l}\text { Average amount of cereal crop } \\
\text { produces per year }\end{array}$ & 170 & 0 & 120 & 13.47 & 17.191 \\
\hline $\begin{array}{l}\text { Amount of average expense } \\
\text { used for cereal crop production }\end{array}$ & 170 & 0 & 30000 & 2865.0 & 4861.645 \\
\hline $\begin{array}{l}\text { Amount of average income gets } \\
\text { by selling cereal crop } \\
\text { production }\end{array}$ & 170 & 0 & 72000 & 7727.6 & 13014.256 \\
\hline $\begin{array}{l}\text { Amount of average vegetables } \\
\text { and fruit produced per year }\end{array}$ & 170 & 0 & 200 & 69.56 & 40.116 \\
\hline $\begin{array}{l}\text { Amount of average expense } \\
\text { used for production of } \\
\text { vegetable and fruit per year in } \\
\text { birr }\end{array}$ & 170 & 0 & 60000 & 13714.12 & 11542.966 \\
\hline $\begin{array}{l}\text { Amount of average income gets } \\
\text { from producing vegetable and } \\
\text { fruit per year in birr }\end{array}$ & 170 & 0 & 220000 & 66451.18 & 35152.816 \\
\hline
\end{tabular}


Socio-Economic Benefit of Lake Ecosystem (In Case of Lake Ziway)

Average amount of vegetable and fruit produced per year was 69.56Qunital per year by SSIU respondents and minimum and maximum amount of vegetable and fruit produced were 0 and 200Quintal per year respectively in addition $61.7 \%$ of SSIU respondents were produced vegetable and fruit between 18 and 80Quintal per year (Table 4). Average amount of expense incurred for vegetable and fruit production was 13,714birr per year also the minimum and maximum amount of cost incurred for vegetable and fruit production by SSIU were 0 and 60,000birr per year. Also $78.2 \%$ of SSIU respondents were incurred cost for vegetable and fruit production between 1,500 and 20,000birr per year. In addition, income get by SSUI respondents with selling vegetable and fruit production, based on this average income get with selling of vegetable and fruit production is 66,451birr per year and minimum and maximum amount of income get by selling vegetable and fruit by SSIU are 0 and 220,000birr per year. Among the respondents $82.3 \%$ get income between 7,200 and 93,000birr per year from vegetable and fruit production by SSIU.

\subsection{Comparing Economical Benefit of Fishermen and Small Scale Irrigation Users (SSIU) from Lake Ziway Ecosystem}

In order to compare the economic benefit of fishermen and Small Scale Irrigation Users from Lake Ziway the study used by comparing their total production amount of expense incurred for their production and amount of income obtained from selling their products in the market by using independent sample $\mathrm{T}$ test. Mean total production of fish, cereal crop production and vegetable and fruit production of small scale irrigation users was $8,363.8 \mathrm{Kg}$ per year. On the other hand, the mean total productions of fishermen were $2,956.3 \mathrm{Kg}$ per year in addition from their mean difference shows that total mean production of SSIU is higher than the total mean production of fishermen by $5,407.5 \mathrm{Kg}$ per year (Table 5). Based on their total mean production the study test their differences by using independent sample $T$-test, the result show that their mean difference is statistically differ each other because with 0.005 of confidence the significance level is 0.00 with considering of equality of variance so that their total mean production statistically differ (Mekonnen G. and Yared W., 2018 and Tafesse K., 2008). This means the total production of small scale irrigation users were got more amount of production than fishermen per year with statistical significant difference.

Table 5: Comparing of total mean production of fishermen and SSIU

\begin{tabular}{|c|c|c|c|c|c|c|c|c|c|c|}
\hline \multirow{3}{*}{$\begin{array}{l} \\
\\
\text { Total } \\
\text { production }\end{array}$} & & \multicolumn{2}{|c|}{$\begin{array}{l}\text { Levene's Test } \\
\text { for Equality of } \\
\text { Variances }\end{array}$} & \multicolumn{7}{|c|}{ t-test for Equality of Means } \\
\hline & & \multirow[t]{2}{*}{$\mathrm{F}$} & \multirow[t]{2}{*}{ Sig. } & \multirow[t]{2}{*}{$\mathrm{t}$} & \multirow[t]{2}{*}{$\mathrm{df}$} & \multirow[t]{2}{*}{$\begin{array}{l}\text { Sig. (2- } \\
\text { tailed) }\end{array}$} & \multirow[t]{2}{*}{$\begin{array}{l}\text { Mean } \\
\text { Differe } \\
\text { nce } \\
\end{array}$} & \multirow[t]{2}{*}{$\begin{array}{l}\text { Std. Error } \\
\text { Difference }\end{array}$} & \multicolumn{2}{|c|}{$\begin{array}{l}\text { 95\% Confidence } \\
\text { Interval of the } \\
\text { Difference }\end{array}$} \\
\hline & & & & & & & & & Lower & Upper \\
\hline production & $\begin{array}{l}\text { Equal } \\
\text { variances } \\
\text { assumed }\end{array}$ & 47.120 & .000 & 13.59 & 338 & . 000 & 5407.5 & 397.77694 & 4625 & 6189.9 \\
\hline & $\begin{array}{l}\text { Equal } \\
\text { variances } \\
\text { not } \\
\text { assumed }\end{array}$ & & & 13.59 & 297.2 & . 000 & 5407.50 & 397.77694 & 4624 & 6190.3 \\
\hline
\end{tabular}

This study also used total mean expense for comparing of economic benefit of fishermen and small scale irrigation users. From the result total mean expense of SSIU for their total production was16, 911 birr per year and total mean expense of fishermen for their total production was 12,777.3 birr per year (Table 6). And their mean difference was 4,133.6birr and their differences were statistically significance at 0.005 confidences at significance level 0.001 with considering of equality of variance. This implied that total expense of production of small scale irrigation users had more total expense than fishermen. 
Gebremedhin et al., Adv. J Social Sci.; Vol. 6 Issue 1, pp: 1-9, 2020

Table 6 Comparing of total mean expense for production of fishermen and SSIU

\begin{tabular}{|c|c|c|c|c|c|c|c|c|c|c|}
\hline \multirow{5}{*}{$\begin{array}{l} \\
\\
\text { Total } \\
\text { expense }\end{array}$} & & \multicolumn{2}{|c|}{$\begin{array}{l}\text { Levene's Test } \\
\text { for Equality of } \\
\text { Variances }\end{array}$} & \multirow{2}{*}{$\mathrm{t}$} & \multicolumn{6}{|c|}{ t-test for Equality of Means } \\
\hline & & $\mathrm{F}$ & Sig. & & \multirow[t]{2}{*}{$\mathrm{df}$} & \multirow[t]{2}{*}{$\begin{array}{l}\text { Sig. } \\
(2- \\
\text { tailed) }\end{array}$} & \multirow[t]{2}{*}{$\begin{array}{l}\text { Mean } \\
\text { Differ } \\
\text { ence }\end{array}$} & \multirow[t]{2}{*}{$\begin{array}{l}\text { Std. } \\
\text { Error } \\
\text { Differe } \\
\text { nce }\end{array}$} & \multicolumn{2}{|c|}{$\begin{array}{l}95 \% \\
\text { Confidence } \\
\text { Interval of the } \\
\text { Difference }\end{array}$} \\
\hline & & & & & & & & & Lower & Upper \\
\hline & $\begin{array}{l}\text { Equal } \\
\text { variances } \\
\text { assumed }\end{array}$ & 10.76 & .001 & 3.370 & 338 & .001 & 4133.5 & 1226.7 & $\begin{array}{l}1720 . \\
5\end{array}$ & 6546 \\
\hline & $\begin{array}{l}\text { Equal } \\
\text { variances } \\
\text { not } \\
\text { assumed }\end{array}$ & & & 3.370 & 326.6 & .001 & 4133.5 & 1226.74 & $\begin{array}{l}1720 . \\
2\end{array}$ & 6546 \\
\hline
\end{tabular}

The other way of comparing economic benefit of fishermen and SSIU who lived on the western shoreline using in this study was total mean income got from their production. Total mean income of SSIU from their production was 75,189 birr per year and total mean income of fishermen was 52,926 birr per year (Table 7).

Table 7: Comparing of total mean income of SSIU and fishermen

\begin{tabular}{|c|c|c|c|c|c|c|c|c|c|c|}
\hline & & \multicolumn{2}{|c|}{$\begin{array}{l}\text { Levene's Test } \\
\text { for Equality of } \\
\text { Variances }\end{array}$} & \multicolumn{7}{|c|}{ t-test for Equality of Means } \\
\hline & & $\mathrm{F}$ & Sig. & $\mathrm{t}$ & $\mathrm{df}$ & $\begin{array}{l}\text { Sig. } \\
(2- \\
\text { tailed })\end{array}$ & $\begin{array}{l}\text { Mean } \\
\text { Differen } \\
\text { ce }\end{array}$ & $\begin{array}{l}\text { Std. } \\
\text { Error } \\
\text { Differe } \\
\text { nce }\end{array}$ & \multicolumn{2}{|c|}{$\begin{array}{l}95 \% \\
\text { Confidence } \\
\text { Interval of the } \\
\text { Difference }\end{array}$} \\
\hline \multirow{3}{*}{$\begin{array}{l}\text { Total } \\
\text { income }\end{array}$} & & & & & & & & & Lower & Upper \\
\hline & $\begin{array}{l}\text { Equal } \\
\text { variances } \\
\text { assumed }\end{array}$ & .600 & .439 & 5.363 & 338 & .000 & 22262.97 & 4150.93 & 14098 & 30428 \\
\hline & $\begin{array}{l}\text { Equal } \\
\text { variances } \\
\text { not assumed }\end{array}$ & & & 5.363 & 337.26 & .000 & 22262.97 & 4150.93 & 14097 & 30427 \\
\hline
\end{tabular}

And their mean income difference was 22,263 birr per year and their mean income difference was statistically significance because at 0.005 confidence at significance level of 0.00 this showed that the significance level was below 0.005 so that by accepting the alternative hypothesis then rejecting null hypothesis. From the result it showed total income of small scale irrigation users were more statistically more than fishermen total income got from their production from ecosystem of Lake Ziway. Based on above ways of comparing, SSIU have more economical benefits from Western shoreline because of SSIU had higher total production amount and total income from their production than fishermen from Western shoreline of Lake Ziway.

\section{Conclusions}

From all other ecosystem services water related ecosystem services held higher percentage of users. For example, $81.8 \%$ of fishermen respondents used drinking water for human and livestock from Lake Ziway, 
Socio-Economic Benefit of Lake Ecosystem (In Case of Lake Ziway)

90.6\% obtained services of bathing and swimming from Lake Ziway and $87.6 \%$ got water for washing their cloths. And in other side $100 \%$ of SSIU respondents obtained water used for irrigation from Lake Ziway, $87 \%$ of SSIU obtained bathing and swimming services, $84.1 \%$ used water for human and livestock from western shoreline of Lake Ziway. From food related ecosystem services 100\% of fishermen respondents got fish from Lake Ziway and 15.3\% of SSIU respondents obtained bee hive from Lake Ziway ecosystem. Both fishermen and SSIU obtained energy and raw material services from Lake Ziway. From ecosystem services related to cultivation and organic fertilizer, $41.8 \%$ fishermen got weed and grass and $15.3 \%$ of fishermen produce cereal crop from Lake Ziway ecosystem. And SSIU also get cultivation and organic fertilizer services from Lake Ziway among these $97.1 \%$ SSIU respondents produced vegetable and fruit production, $61.2 \%$ SSIU respondents produced cereal crop, and $50 \%$ of SSIU respondents got weed and grass from Western shoreline of Lake Ziway. Lake Ziway also gave services related genetic and medicinal resources to local community for example $37.6 \%$ of SSIU respondents used medicinal plants and $8.2 \%$ fishermen respondents for also used medicinal plants from Western shoreline of Lake Ziway. Mean total production of fishermen was $2956.3 \mathrm{Kg}$ per year and mean total production of SSIU was $8363.8 \mathrm{Kg}$ per year. And from independent T-test, the amount of mean total production of SSIU was significantly higher than fishermen total mean production. Mean total expense of SSIU for their production was 16,910.9 birr per year and mean total expense of fishermen was 12,777.3 birr per year. And from comparing their mean total expense, the mean total expenses of SSIU were significantly higher than fishermen mean total expense. Total mean income of SSIU was 75,188.9 birr per year and total mean income of fishermen was 52,926 birr per year from their production of cereal crop, vegetable and fruit production and fish catching. And when comparing their total mean income, total mean income of SSIU was significantly higher than that of fishermen.

\section{Declarations}

\subsection{Acknowledgements}

I express my immense gratitude to my advisors Dr. Alemu Mekonnen, I thank Dr. Alemu M. for his critical helping and comment in preparing methodology, model specification and also in analyzing the data and fast response to my questions. I would also like to thank the funding agency, Horn of Africa Regional Environment Centre/Network. My deepest gratitude and appreciation go to Ato Amare Hailu who is staff of HoAREN/C Ziway branch for helping in field work with giving information about the areas and coordinating field work and I would like to thank for survey questionnaire distributers in collection of survey data. I am also extremely grateful to ATJK and Dugda woreda administration staffs and Ziway fishery research institute with giving relevant information and written documents and reports which helps for this research.

\subsection{Competing Interests}

The authors declared that no conflict of interest exist in this publication.

\section{How to Cite this Article:}

Gebremedhin, G., \& Belliethathan, S. (2019). Socio-Economic Benefit of Lake Ecosystem (In Case of Lake Ziway). Advanced Journal of Social Science, 6(1), 1-9. doi: 10.21467/ajss.6.1.1-9

\section{References}

Alan D. Steinmana,, Bradley J. Cardinale, Wayne R. Munns Jr, Mary E. Ogdahl, J.DavidAllan, TedAngadi ,Sarah Bartlett, Kate Brauman, Muruleedhara Byappanahalli, MattDossi, Diane Dupont, Annie Johns, Donna Kashian, Frank Lupi, Peter McIntyre ,ToddMiller, Michael Moore, Rebecca Logsdon Muenichp,Rajendra Poudelq, James Price, Bill Provencher, AnneRea, Jennifer Read, Steven Renzetti ,Brent Sohngen , Erika Washburn. 2017. Ecosystem services in the Great Lakes. Journal of Great Lakes Research.

Brent M., Joseph K., Meshack N., Daniel K., Anantha K., Thomas B., 2009. Tradeoffs, synergies and traps among ecosystem services inthe Lake Victoria basin of East Africa. environmental science \& policy 12.

Christina P., Bo J., Theodore J., Kai N., Dennis P., Dongchun M., and Zhiyun O. 2017. Lake and wetland ecosystem services measuring water storage and local climate regulation,Water Resour. Res.,53, 3197-3223. 
Gebremedhin et al., Adv. J Social Sci.; Vol. 6 Issue 1, pp: 1-9, 2020

EFTEC.2005. The Economic, Social and Ecological Value of Ecosystem Services: A Literature Review Final report for the Department for Environment, Food and Rural Affairs (DEFRA). London, UK.

Eyasu Elias, Weldemariam Seifu, Bereket Tesfaye and Wondwosen Girmay. 2019. Impact of land use/cover changes on Lake Ecosystem of Ethiopia central rift valley. Cogent Food \& Agriculture.

Fan W., Shaoliang Z., Huping H., Yongjun Y., and Yunlong G. 2019. Assessing the Changes of Ecosystem Services in theNansi Lake Wetland, China. School of Environmental Science and Spatial Informatics, China University of Mining and Technology.

Felegeselam Y. 2003. Management of Lake Ziway Fisheries in Ethiopia. Msc thesis

Hannah M., David H., Graeme D., Jonathan A., Christopher M. 2019. Economic and ecosystem costs and benefits of alternative land use and management scenarios in the Lake Rotorua, New Zealand, catchment. Global Environmental Change, Elsevier ScienceDirect. in international fisheries management, university of Tromos, Norway.

Janet G., Ciara R., Nicolas L., Frances I., Monika Z., Karen B., Neville A., Paul W., 2008. Ecosystem Services A Guide for Decision Makers. World resource institute.

Ke Z., Xiangdong Y., Giri K., Qi L., \& Ji S. 2018. Freshwater lake ecosystem shift caused by social-economic transitions in Yangtze River Basin over the past century.

Konstantine O., Richard O., Paul O. 2005. Distribution of economic benefits from the fisheries of Lake Victoria. The State of the Fisheries Resources of Lake Victoria and their Management: Proceedings of the Entebbe Regional Stakeholders' Workshop. 24-25 February 2005, Entebbe, Uganda. ISBN: 9970-713-10-2 (Pp 124-131).

Małgorzata C. 2017. Changing values of Lake Ecosystem services as a result of bacteriological contamination on Lake Trzesiecko and Lake Wielimie, Poland. Environmental and Socioeconomics studies, University of Silesiain Katowice.

Mathewos H., 2011. Ecosystem structure, trophic link and functioning of a shallow rift valley lake: the case of Lake Ziway, Ethiopia. A Thesis Submitted to the School of Graduate Studies, Addis Ababa University in Partial Fulfillment of the Requirements for the Degree of Master of Science in Biology Fisheries and Aquatic Sciences Stream.

Mekonnen G. and Yared W. 2018. Reversing the Degradation of Ethiopian Wetlands": Is it Unachievable Phrase or A Call to Effective Action?

Petra S., Tesfaye W., Eskedar T. and Getachew S. 2009. Past, Current and Potential Production of Fish in lake Ziway. Capacity Development and Institutional Change Programme Wageningen International, the Netherlands.

Rgalem D., 2018. Analysis of Economic Value of Lake Ziway: An Application of Contingent Valuation Method. Journal of Resources Development and Management.

Rob B., Alison H., Robin P. 2017. Ecosystem Services A summary of research outputs supported or facilitated by the Environmental Change Programme of the Scottish Government's Portfolio of Strategic Research 2011-2016.

Russi D., Ten P., Farmer A., Badura T., Coates D., Förster J., Kumar R., Davidson N.2013. The Economics of Ecosystems and Biodiversity for Water and Wetlands. IEEP, London and Brussels; Ramsar Secretariat, Gland.

Sabine H., Soren B., Erik J., Annelies J., Sarian K. 2017. Translating Regime Shifts in Shallow Lakes into Changes in Ecosystem Functions and Services. Oxford University Press on behalf of the American Institute of Biological Sciences vol. 67 No. 10.

Tafesse K. 2008. Integrated Assessment of ecosystem services and stakeholder analysis of Abijata-Shalla Lakes National Park, Ethiopia. MSc Thesis in Environmental Sciences, Environmental systems Analysis group Environmental systems Analysis group Wageningen, UR.

Tesfau B., Brook L., Seyoum M., 2018. Interaction of local community and wetlands: The case of Lake Ziway shore area, Ethiopia. International Journal of Scientific and Research Publications, Volume 8, Issue 2.

Walter V., Stephen R., Harold A., Kartlk C. 2006. Nature: The many benefit of ecosystem services. Nature Vol 443.

Publish your research article in AIJR journals-

$\checkmark \quad$ Online Submission and Tracking

$\checkmark$ Peer-Reviewed

$\checkmark$ Rapid decision

$\checkmark \quad$ Immediate Publication after acceptance

$\checkmark \quad$ Articles freely available online

$\checkmark \quad$ Retain full copyright of your article.

Submit your article at journals.aijr.in
Publish your books with AIJR publisher-

$\checkmark \quad$ Publish with ISBN and DOI.

$\checkmark$ Publish Thesis/Dissertation as Monograph.

$\checkmark$ Publish Book Monograph.

$\checkmark$ Publish Edited Volume/ Book.

$\checkmark \quad$ Publish Conference Proceedings

$\checkmark$ Retain full copyright of your books.

Submit your manuscript at books.aijr.org 